\title{
Study of Internal Factors and External Factors of Insurance Companies Towards Company Value (Study on Indonesia Stock Exchange)
}

\author{
Chairul Anam ${ }^{1 *}$ \\ ${ }^{1}$ Management Study Program, Trunojoyo Madura University, Indonesia
}

\begin{abstract}
The purpose of this study is to determine the influence of the company's external factors with proxies: inflation and interest rates, and the company's internal factors with proxies: Return on Equity, and Debt to Equity Ratio partially and simultaneously to firm value in insurance sector companies listed on the Stock Exchange Indonesia. The research method used in this study is quantitative research methods, with the object of research of insurance companies listed on the Indonesia Stock Exchange, amounting to 14 companies. This study used a purposive sampling technique that produced 8 companies as the research sample. The research data source uses secondary data in the form of documents including data about the company's general description and financial statements of insurance companies on the Indonesia Stock Exchange (IDX) for 5 years. The results of this study indicate inflation, interest rates, Return on Equity, and Debt to Equity Ratio simultaneously have a positive but not significant effect on company value, then partially the other 3 variables, namely inflation, interest rates, and Debt to Equity Ratio have a positive effect but not significant to firm value, while variable Return on Equity has a positive and significant effect on firm value. Based on the coefficient of determination of 0.138 this shows the influence of 4 variables, namely inflation, interest rates, return on equity, debt to equity ratio of $13.8 \%$ while the remaining $86.2 \%$ is influenced by other factors, for example: the level of competition, policy company, developments in macroeconomic conditions.
\end{abstract}

\section{Introduction}

In the era of industrial revolution 4.0 competition between companies was increasingly competitive, including companies in Indonesia competing to enhance high competitiveness and excellence in the business and economic world. Competition between companies is not except with insurance companies. The increasing prevalence of insurance companies in Indonesia makes competition very tight to make its existence in the insurance world. In

* Corresponding author: chairul.anam199@gmail.com 
addition, it is undeniable that human beings need protection at any time when they are anywhere and even at any time. Every normal human being must have aspirations to always improve or improve their standard of living in order to pursue physical and spiritual wellbeing.

The development of the insurance industry in Indonesia is quite prospective, the general insurance industry has the opportunity to grow by double digits in 2019, although this estimate is strongly influenced by the political situation next year. If the election runs well and is conducive, then post-election economic activities are believed to be able to run faster (Julian Noor, 2018).

The development of insurance companies is influenced by external factors and company internal factors. External factors in this study are proxied with inflation and interest rates, while the internal factors of the company are proxied with profits as measured by Return on Equity (ROE) and debt as measured by the Debt Equity Ratio (DER)

In an economic system, inflation is an economic indicator that describes the decline in the value of the rupiah, and this condition is characterized by the increase in the prices of goods needed in the market (Noer Irawan and Hamid, 2013). Increasing inflation can reduce people's purchasing power, because the prices of goods need to increase, while people's income remains. Inflation is often a problem, especially if the government is unsuccessful or unable to control its growth rate.

According to Gusnardi (2017) inflation is an increase in the price of goods continuously. Inflation is low and reflects the stability of good economic growth, the stability and low benefits of inflation for companies will certainly increase profits for companies from rising goods prices, on the contrary high inflation will cause the value of goods and services to rise sharply so that the emergence of speculative actions from investors will detrimental to the company even the economy of a country will be negatively affected, such as: the decline in value and trust in the currency that will decrease, with this in mind the government has one of the tools to control inflation, namely interest rates. Furthermore Demir (2007), states that inflation has a significant negative effect on the profitability of manufacturing companies, as well as Pareira (2010) states that there is a negative relationship between inflation and stock prices.

Hamidah (2015) said that the high level of inflation would reduce wealth in the form of money and would reduce people's purchasing value. The existence of this is caused by several factors, one of which is the stronger the community will be a demand for a particular item, because it increases the cost of producing an item. Inflation that occurs in a country is also very influential on interest rates because every time there is an increase in the inflation rate it will be followed by an increase in BI interest rates. With this, the government policy to reduce the inflation rate by raising interest rates means to reduce the amount of money in circulation and attract public funds so as to reduce inflation. According to Hafiz Syamid Ardhi (2017) Interest rates are a tool for the central bank of a country in maintaining the stability of a country's economic growth, interest rates are also one of the macro variables that need to be considered that can affect the value of the company. An increase in interest rates will reduce corporate profits and cause

In the era of industrial revolution 4.0 competition between companies was increasingly competitive, including companies in Indonesia competing to enhance high competitiveness and excellence in the business and economic world. Competition between companies is not except with insurance companies. The increasing prevalence of insurance companies in Indonesia makes competition very tight to make its existence in the insurance world. In addition, it is undeniable that human beings need protection at any time when they are anywhere and even at any time. Every normal human being must have aspirations to always improve or improve their standard of living in order to pursue physical and spiritual wellbeing. 
The development of the insurance industry in Indonesia is quite prospective, the general insurance industry has the opportunity to grow by double digits in 2019, although this estimate is strongly influenced by the political situation next year. If the election runs well and is conducive, then post-election economic activities are believed to be able to run faster (Julian Noor, 2018).

The development of insurance companies is influenced by external factors and company internal factors. External factors in this study are proxied with inflation and interest rates, while the internal factors of the company are proxied with profits as measured by Return on Equity (ROE) and debt as measured by the Debt Equity Ratio (DER)

In an economic system, inflation is an economic indicator that describes the decline in the value of the rupiah, and this condition is characterized by the increase in the prices of goods needed in the market (Noer Irawan and Hamid, 2013). Increasing inflation can reduce people's purchasing power, because the prices of goods need to increase, while people's income remains. Inflation is often a problem, especially if the government is unsuccessful or unable to control its growth rate.

According to Gusnardi (2017) inflation is an increase in the price of goods continuously. Inflation is low and reflects the stability of good economic growth, the stability and low benefits of inflation for companies will certainly increase profits for companies from rising goods prices, on the contrary high inflation will cause the value of goods and services to rise sharply so that the emergence of speculative actions from investors will detrimental to the company even the economy of a country will be negatively affected, such as: the decline in value and trust in the currency that will decrease, with this in mind the government has one of the tools to control inflation, namely interest rates.

Hamidah (2015) said that the high level of inflation would reduce wealth in the form of money and would reduce people's purchasing value. The existence of this is caused by several factors, one of which is the stronger the community will be a demand for a particular item, because it increases the cost of producing an item. Inflation that occurs in a country is also very influential on interest rates because every time there is an increase in the inflation rate it will be followed by an increase in BI interest rates. With this, the government policy to reduce the inflation rate by raising interest rates means to reduce the amount of money in circulation and attract public funds so as to reduce inflation. According to Hafiz Syamid Ardhi (2017) Interest rates are a tool for the central bank of a country in maintaining the stability of a country's economic growth, interest rates are also one of the macro variables that need to be considered that can affect the value of the company. An increase in interest rates will reduce company profits and cause stock prices fell. According to Sujoko and Ugy (2007) said a high interest rate would reduce investors' interest to invest their funds into the capital market and prefer to invest in deposits so that stock trading activities would decrease and the value of the company would also decline and vice versa, if the value of the company increased then the performance of the company must be improved so that a company can benefit.

Furthermore, William T. Sucuahi et al (2016), states that based on the results of the study show that even though the inflation rate can positively influence the growth of stock prices among diversified companies in the Philippines, this influence is not significant. The inflation rate is not the main factor for the growth of stock prices. Acquiring the company's shares is the best strategy for investors even though inflation fluctuates and is unstable. Thus, the concept that inflation can affect stock prices cannot be applied to companies listed on the Stock Exchange. The results of this study are expected to help investors understand risk and hedge investments in the making and evaluation of monetary policy.

Companies must also have to be able to effectively manage their sources of funds in order to increase net income. As for the type of ratio used to analyze the company's financial performance, one of them is the profitability ratio. This profitability ratio is a ratio 
to assess and measure the ability of a company's value in obtaining profits or profits by using the capital owned by the company itself. As for the part of the profitability of the profitability ratio is Return On Equity (ROE) which aims to measure the ability of a company to obtain profit after tax by using its own capital owned by the company. The higher Return On Equity (ROE) will increase the demand for company shares. The high stock price will determine the return that will be received by investors. Dewi and Wirajaya (2013: 363) said that the higher the company gets a profit, the greater the return expected by investors so that it can make the company's value better. Prasetyorini (2013) says that profitability has a positive and significant effect on firm value.

Company management must be observant in collaborating with other companies in order to optimize cash in the company. If the company experiences financial difficulties and is threatened with bankruptcy due to excessive use of debt so that it is unable to fulfill its obligations, the loss can be in the form of dividend reduction or bankruptcy, in order to find out how much debt is used to meet company spending. One of the calculation of this ratio is the Debt To Equity Ratio, which is to measure the size of the use of long-term debt when compared with the equity in the company. Noerirawan and Muid (2013) say that Debt to Equity Ratio (DER) has a negative but not significant effect on firm value. Caused by the existence of debt that is too high and has an impact on the lack of public confidence in the company.

Based on the description above, the following hypotheses can be formulated:

$\mathrm{H} 1$ : Inflation affects the value of insurance companies

$\mathrm{H} 2$ : Interest rates affect the value of insurance companies

H3 : Profitability (Return On Equity) affects the value of the insurance company

H4 : Debt Equity Ratio affects the value of the insurance company

H5 : Inflation,interest rate,return on equity and debt equity ratio affects the value of insurance companies

\section{Research methods}

\subsection{Research data}

The type of data used in this study is quantitative data. The dependent variable used in this study is company value which is a value for measuring company performance which is often associated with investor perceptions of the company's stock price. While the independent variables used in this study are the company's external factors which include: Inflation, Interest Rates, and internal company factors which include: profitability as measured by Return On Equity (ROE), and debt as measured by Debt To Equity Ratio (DER) which is associated with an assessment of the value of the company.

\subsection{Object of research}

This research was conducted at an insurance company with components listed on the Indonesia Stock Exchange. The time of the research conducted in this study is that it starts from 2013 until 2017. According to the data obtained from the Indonesia Stock Exchange which is accessed through the official website of the Indonesia Stock Exchange (www.idx.co.id).

\subsection{Population}

The population in this study were 14 Insurance Companies Listed on the IDX (Indonesia Stock Exchange) for the period 2013-2017. 
Table 1. Population Research

\begin{tabular}{|c|c|c|c|}
\hline No & Kode Perusahaan & Nama Perusahaan & IPO \\
\hline 1 & ABDA & Asuransi Bina Dana Arta Tbk & 06 Juli 1989 \\
\hline 2 & AHAP & Asuransi Harta Aman Pratama Tbk & 14 Sep 1990 \\
\hline 3 & AMAG & Asuransi Multi Artha Guna Tbk & 23 Des 2005 \\
\hline 4 & ASBI & Asuransi Bintang Tbk & 29 Nop 1989 \\
\hline 5 & ASDM & Asuransi Dayin Mitra Tbk & 15 Des 1989 \\
\hline 6 & ASJT & Asuransi Jaya Tania Tbk & 23 Des 2003 \\
\hline 7 & ASMI & Asuransi Mitra Maparya Tbk & 16 Januari 2014 \\
\hline 8 & ASRM & Asuransi Ramayana Tbk & 19 Maret 1990 \\
\hline 9. & JMAS & Asuransi Jiwa Syariah Jasa Mitra Abadi Tbk & 18-Desember-2017 \\
\hline 10 & LPGI & Lippo General Insurance Tbk & 06-September-2005 \\
\hline 11 & MREI & Maskapai Reasuransi Indonesia Tbk & 04-September-1989 \\
\hline 12 & MTWI & Malacca $\quad$ Trust Wuwungan Insurance Tbk & 11-Oktober-2017 \\
\hline 13 & PNIN & Paninvest Tbk & 20-September-1983 \\
\hline 14 & VINS & Victoria Insurance Tbk & 28-September-2015 \\
\hline
\end{tabular}

\subsection{Sample}

By using purposive sampling method that is by limiting the sampling that will be examined based on certain criteria, namely:

a) Insurance companies registered on the IDX from 2013 to 2017.

b) Insurance Companies that issue financial statements during the period 2013-2017.

c) The company's financial statements contain a balance sheet, profit / loss, cash flow that has been audited by a public accountant

d) The company uses the Rupiah unit as the currency in its financial statements.

e) The Company has the end of the financial statement period 31 December. 
Table 2. Research Samples

\begin{tabular}{|c|l|l|r|}
\hline No & \multicolumn{1}{|c|}{ Kode Perusahaan } & \multicolumn{1}{|c|}{ Nama Perusahaan } & \multicolumn{1}{|c|}{ IPO } \\
\hline 1 & ABDA & Asuransi Bina Dana Arta Tbk & 06 Juli 1989 \\
\hline 2 & AHAP & Asuransi Harta Aman Pratama Tbk & 14 Sep 1990 \\
\hline 3 & ASBI & Asuransi Bintang Tbk & 29 Nop 1989 \\
\hline 4 & ASJT & Asuransi Jaya Tania Tbk & 23 Des 2003 \\
\hline 5 & ASRM & Asuransi Ramayana Tbk & 19 Maret 1990 \\
\hline 6 & ASDM & Asuransi Dayin Mitra Tbk & 15 Des 1989 \\
\hline 7 & LPGI & Lippo General Insurance Tbk & 06 Sept 2015 \\
\hline 8 & MREI & Maskapai Reasuransi Indonesia Tbk & 04 Sept1 989 \\
\hline
\end{tabular}

\section{Research results and discussion}

\subsection{Research result}

The research data in the form of secondary data obtained from the Indonesia Stock Exchange was processed and analyzed using multiple regression analysis techniques.

\subsubsection{Multiple linear regression analysis}

Multiple linear regression analysis is used to measure the effect of independent variables on dependent variables together or partially. This measurement of influence involves four independent variables $(\mathrm{X})$ and a dependent variable $(\mathrm{Y})$,

The regression equation with multiple linear in this study are:

$$
Y=a+b 1 X 1+b 2 X 2+b 3 X 3+b 4 X 4+e
$$

Information :

a: Constant

Y: Price Book Value

e: Standard Error Regression X1: Inflation

X2: Interest Rate

X3: ROE

X4: DER

B1-4: Coefficient 


\subsubsection{Hypothesis testing}

\subsubsection{Test $t$}

The $\mathrm{T}$ test is used to determine whether the independent variables partially influence the dependent variable. To test whether each independent variable has a significant effect on the dependent variable partially with $\alpha=0.05$. Then the way that is done is:

a) If $t$ count $<t$ table then Ho will be accepted, meaning that the independent variable does not have a significant influence on the dependent variable.

b) If $t$ count $>t$ table then Ho will be rejected, meaning that the independent variable has a significant influence on the dependent variable

c) If $\mathrm{Ha}$ is accepted if the probability is less than 0.05 (a), it means that there is a significant influence between the independent variables on the dependent variable.

\subsubsection{Test $F$}

The $\mathrm{F}$ test is used to determine whether the independent variables together have a significant effect on the dependent variable. The basis for making test decisions is:

a) If the significant value of the test is $\mathrm{F}>0.05$ then Ho will be accepted, meaning that the variation of the regression model used does not succeed in explaining the independent variable.

b) If the significant value of the test is $F<0.05$, Ho will be rejected, meaning that the variation of the regression model used successfully explains the independent variable The formula used is:

$$
F=\frac{R^{2} /(k-1)}{(1-R)^{2} /(n-k)}
$$

Information :

$\mathrm{F}=\mathrm{F}$ count which is then consulted with $\mathrm{F}$ table

$\mathrm{R} 2=$ Coefficient of determination

$\mathrm{n}=$ Number of samples

$\mathrm{k}=$ Number of variables

\subsubsection{Determination coefficient test ( $r 2)$}

According to Ghozali (2013: 97) the coefficient of determination (R2) essentially measures how far the model's ability to explain the variation of the dependent variable. The coefficient of determination is between zero and one. The small value of $\mathrm{R} 2$ means that the ability of independent variables to explain variations in the dependent variable is very limited. A value close to one means that the independent variables provide almost all the information needed to predict the dependent variable.

\subsubsection{Hypothesis testing}

Based on the results of multiple regression data analysis techniques using the SPSS statistical program the following results are obtained 


\begin{tabular}{|c|c|c|c|c|c|c|c|c|c|c|}
\hline \multirow[t]{2}{*}{ Model } & \multicolumn{2}{|c|}{\begin{tabular}{|c|}
$\begin{array}{c}\text { Unstandardized } \\
\text { Coefficients }\end{array}$ \\
\end{tabular}} & \multirow{2}{*}{\begin{tabular}{|c|}
$\begin{array}{c}\text { Standardized } \\
\text { Coefficients }\end{array}$ \\
Beta \\
\end{tabular}} & \multirow[t]{2}{*}{$\mathbf{t}$} & \multirow[t]{2}{*}{ Sig. } & \multicolumn{3}{|c|}{ Correlations } & \multicolumn{2}{|c|}{$\begin{array}{l}\text { Collinearity } \\
\text { Statistics }\end{array}$} \\
\hline & B & $\begin{array}{c}\text { Std. } \\
\text { Error }\end{array}$ & & & & \begin{tabular}{|l|} 
Zero- \\
order
\end{tabular} & Partial & Part & Tolerance & VIF \\
\hline (Constant) & 1,694 & 2,310 & & ,733 & 468 & & & & & \\
\hline Inflasi & ,471 & ,668 & ,137 & ,705 & ,485 & ,157 & ,118 & ,111 & ,653 & 1,533 \\
\hline 1 Suku bunga &,- 427 & 2,237 &,- 037 &,- 191 & ,850 & ,041 &,- 032 &,- 030 & ,663 & 1,508 \\
\hline ROE & 1,140 & ,548 & ,386 & 2,078 & ,045 & ,330 & ,331 & ,326 & ,714 & 1,401 \\
\hline DER &,- 341 & ,443 &,- 141 &,- 768 &, 447 & ,066 &,- 129 & $9-, 121$ & ,729 & 1,372 \\
\hline
\end{tabular}

\begin{tabular}{|c|c|c|c|c|c|c|c|c|c|}
\hline \multicolumn{10}{|c|}{ Model Summaryb } \\
\hline \multirow[t]{2}{*}{ Model } & \multirow[t]{2}{*}{$\mathbf{R}$} & \multirow{2}{*}{\begin{tabular}{|c|}
$\mathbf{R}$ \\
Square
\end{tabular}} & \multirow{2}{*}{\begin{tabular}{|l|} 
Adjusted R \\
Square
\end{tabular}} & \multirow{2}{*}{$\begin{array}{l}\text { Std. Error of } \\
\text { the Estimate }\end{array}$} & \multicolumn{4}{|c|}{ Change Statistics } & \multirow{2}{*}{$\begin{array}{l}\text { Durbin- } \\
\text { Watson }\end{array}$} \\
\hline & & & & & $\begin{array}{l}\text { R Square } \\
\text { Change }\end{array}$ & $\begin{array}{c}\text { F } \\
\text { Change }\end{array}$ & df1 df2 & \begin{tabular}{|c|} 
Sig. F \\
Change
\end{tabular} & \\
\hline 1 &, $372 \mathrm{a}$ & , 138 &, 040 & ,65965 & ,138 & 1,402 & $4 \quad 35$ & ,254 & ,727 \\
\hline \multicolumn{10}{|c|}{ a. Predictors: (Constant), inflai, sukubunga, ROE,DER } \\
\hline \multicolumn{10}{|c|}{ b. Dependent Variable: PBV } \\
\hline
\end{tabular}

\begin{tabular}{|c|l|r|r|r|r|r|}
\hline \multicolumn{7}{|c|}{ ANOVAa } \\
\hline \multicolumn{2}{|c|}{ Model } & Sum of Squares & \multicolumn{1}{|c|}{ df } & Mean Square & F & Sig. \\
\hline \multirow{3}{*}{1} & Regression & 2,440 & 4 &, 610 & 1,402 &, $254 \mathrm{~b}$ \\
\cline { 2 - 7 } & Residual & 15,230 & 35 &, 435 & & \\
\cline { 2 - 7 } & Total & 17,669 & 39 & & & \\
\hline a. Dependent Variable: PBV & & & \\
\hline
\end{tabular}

\subsection{Discussion}

\subsubsection{Test Coefficient of Determination (r2)}

The Determination Coefficient Test (R2) shows that the proportion of variation in the dependent variable (Company Value) can be explained by independent variables (Inflation, Interest Rate, Return On Equity, and Debt to Equity Ratio) while the remainder can be explained by other variables not included in research.

The value of $\mathrm{R}$ Square is equal to 0.138 which indicates that the independent variable (Company Value) can be explained by the independent variable (Inflation, Interest Rate, 
Return On Equity, Debt To Equity Ratio) which is $13.8 \%$ and the remaining $86.2 \%$ influenced by other factors not explained in the regression model in this study such as: economic conditions, type and quality of products offered, service quality, level of competition in the insurance industry in Indonesia.

\subsubsection{Influence of Inflation on Company Values}

Based on the results of this study there is an influence of inflation on the value of the company in the insurance sector listed on the Indonesia Stock Exchange. The results of this study indicate that the value of $t$ obtained is 0.705 and a significant level of 0.485 is greater than $0.05(0.485>0.05)$ which means that inflation does not significantly influence the value of companies in insurance sector companies listed on the Indonesia Stock Exchange in the 2013 period until 2017. This shows that if the company is able to increase inflation then the value of the company will decrease but the effect is not significant. non-significant results inform that the increase and decrease in inflation is not in line with the value of the company.

Viewed from the point of view of investors Inflation as a company external factor for that management is more focused and pay attention to how the company produces high profits so that it can produce high returns.

Based on the research data, the inflation value fluctuated from year to year, for example in 2013, which was 4.03 and the Company Value was 428.5644, then in 2014 Inflation increased to $107 \%$ to 8.38 and the Company Value was 324,0062, in 2015 moved down $0.2 \%$ to 8.36 and the value of the Company decreased as much as 369.3593, until 2016 Inflation decreased by $0.6 \%$ to 3.35 and the Company Value was 32.6691 The lowest inflation was in the year 2017, which is a decrease of $9 \%$ to 3.02 and a Company Value of 25.4098 .

This is in line with the research conducted by Hamidah (2015) where the results show that inflation does not significantly influence the value of the company. Gusptasari (2013) also said that Inflation had no significant effect on Company Value. This is also consistent with Sangkyun's (1997) study, which states that the inflation rate does not have a significant effect on stock returns that have an impact on the stock prices of manufacturing companies.

\subsubsection{Effect of Interest Rates on Company Values}

Based on the results of this study there is an influence of interest rates on the value of the company in the insurance sector listed on the Indonesia Stock Exchange. The results of this study indicate that the interest rate has no significant effect on the value of the company. With a value of $t$ equal to -0.191 greater than 0.05 , which means that the Interest Rate does not have a significant effect on the Corporate Value of insurance sector companies listed on the Indonesia Stock Exchange from 2013 to 2017.

Based on the results of data analysis can be shown in the interest rate fluctuations in 2013 amounted to $5.77 \%$ with a Company Value of 428.5644 then in the period of 2013 the interest rate increased by $7.02 \%$ with a Company Value of 324,0062 Interest rates in 2014 also increased by $8.16 \%$ with a Company Value of 369.3593 , while for 2015 the interest rate decreased by $7.52 \%$ with a Corporate Value of 32.6691 up to 2017 Interest Rates also decreased by $6.00 \%$ with a Company Value of 25.4098 .

This indicates that the BI rate is more likely to control inflation in the rupiah exchange rate decline not to increase or decrease the value of the company. However, capital market players are not affected by the increase in interest rates due to the increase and decrease in the interest rates are only temporary, and capital market players prioritize long-term returns. 
The results of this study are in line with Khodir's research (2013), saying that interest rates have a negative and not significant effect on firm value. The results of these studies are also consistent with the research of Sujoko and Ugy (2007); Rakhimsyah and Gunawan (2011) say that the interest rates have a negative effect that is not significant on the value of the company.

\subsubsection{Effect of Return On Equity Against Company Values}

Based on the results of this study there is an effect of Return On Equity (ROE) on Corporate Values in the insurance sector listed on the Indonesia Stock Exchange. The results of this study indicate that Return On Equity (ROE) does not have a significant effect on Firm Value. with a t value of 2.078 greater than 0.05 , which means that Return On Equity (ROE) does not have a significant effect on Company Values in insurance sector companies listed on the Indonesia Stock Exchange period 2013 to 2017

Based on the results of data analysis can be shown in the level of value fluctuations Return On Equity (ROE) with an average in 2013 that is equal to 1.4654 with Corporate Value that is equal to 428.5644 , then in 2013 amounted to 1.2989 with Corporate Value that is equal to 324,0062 . Then in 2014 amounted to 1.2472 while the Company Value was 369.3593. In 2015 amounted to 1,1954 with a Company Value of 32,6691. Then in 2017, which is equal to 1.0128 with a Company Value of 25.4098

Return On Equity (ROE) has a significant effect on Firm Value, influential Return on Equity (ROE) on Corporate Values is caused because the profits obtained by the company are stable from year to year and tend not to fluctuate so investors do not hesitate and are confident of the results that the company will get in the future future so that it reflects the company's ability to generate high returns for shareholders. The greater the profits obtained, the greater the ability of the company to pay dividends and will have an impact on increasing the value of the Company. high low value of Return On Equity (ROE) because the company experiences fluctuations in the company's net income, each year the Return On Equity (ROE) decreases starting from 2013-2017. a decrease in Return on Equity (ROE) on Company Value.

The results of the hypothesis testing are in line with the research of Siska Adelina (2014), Anthony Wijaya (2015), and Ria Fihendri (2017) who say that Return On Equity (ROE) significantly influences the Firm Value. But the statement is also not in line with the research conducted by Astriana (2014) saying that profitability does not affect the value of the company.

\subsubsection{Effect of Debt To Equity Ratio on Company Values}

Based on the results of this study there is an influence of the Debt to Equity Ratio (DER) on the Company Value in the insurance sector listed on the Indonesia Stock Exchange. the results of this study indicate that Debt to Equity Ratio (DER) does not significantly influence the value of the company. with a t value of -0.768 greater than 0.05 , which means that the Debt to Equity Ratio (DER) does not have a significant effect on the Company Value in insurance sector companies listed on the Indonesia Stock Exchange from 2013 to 2017

Based on the results of data analysis, it can be shown in the value of the fluctuation of Debt to Equity Ratio (DER) with an average in 2013 that is equal to 19.4463 with Company Value that is equal to 428.5644 , then in 2013 amounted to 18.9815 with Corporate Value namely amounting to 324,0062 . Then in 2014 amounted to 18.8152 while the Company Value was 369.3593. In 2015 it amounted to 17.4232 with a Company Value of 32.6691. Then in 2017 , that is equal to 14,8694 with Company Value that is equal to 25,4098 so that 
it can show that the existence of Debt to Equity Ratio (DER) is not able to increase Company Value.

This shows that the funding decision obtained from debt is not a direct factor that can be considered for investors to invest in the company. Investors need more information on how the management uses these funds as company capital effectively and efficiently to achieve added value for the company.

From year to year the Debt to Equity Ratio (DER) experiences fluctuations that differ only slightly in number so that the value of Debt to Equity Ratio (DER) to Company Value is not significant. the existence of these statements is not in line with the research of Nurchanifia (2011) and Gunawan (2011) saying that Debt to Equity Ratio (DER) has a significant effect on Company Value. But also in line with the research of Pancawati (2009), Sari and Sidiq (2013), Febrianti (2013) said that Debt to Equity Ratio (DER) has a positive effect on Firm Value. Dewi and Wirajaya's research (2013) also found different research results, namely Debt to Equity Ratio (DER) which had a negative and significant effect on Firm Value.

\subsubsection{Effect of Inflation, Interest Rates, Return On Equity (ROE), Debt To Equity Ratio (DER) on Company Value.}

Based on the results of this study there are influences of Inflation, Interest Rate, Return On Equity (ROE), Debt To Equity Ratio (DER) on Corporate Values in the insurance sector listed on the Indonesia Stock Exchange. The results of this study show that inflation, interest rates, return on equity (ROE), debt to equity ratio (DER) did not significantly influence the value of the company. Based on the analysis using SPSS, obtained F count value of 1.261 and a significant level of $F$ of $0.254>0.05$. So that it can be concluded that simultaneously all the independent variables, namely the Inflation, Interest Rate, Return On Equity (ROE), Debt To Equity Ratio (DER) variables did not significantly influence the Company Value in insurance sector companies listed on the Indonesia Stock Exchange,

The results of the regression analysis show the coefficient of determination (R2) that is equal to 0.138 or $13.8 \%$, changes that occur in Corporate Values can be explained by Inflation, Interest Rate, Return On Equity (ROE), Debt To Equity Ratio (DER) while the remainder is $86.2 \%$ is explained by other variables outside the research regression model.

This reflects that it is better that before investing in prospective investors not only pay attention to the internal factors of the company that will be targeted to invest, namely financial performance, but also pay attention to external factors that can also affect the state of the company. Inflation is one indicator to see the economic stability of a region or country that shows an increase in prices of services and goods. Where an economic condition occurs imbalance between demand and demand for products that are higher than the supply so that there is a tendency for price increases. High inflation will cause the purchasing power of money to decline and the level of investor income also decreases. The increase in the inflation value will have an impact on the increase in high operational costs so that the company gets fewer profits and will cause investor interest in investing in the company to decline. Inflation can also be caused by several factors, among others, the increasingly strong desire of the community for a demand for a particular item, due to the increase in bank interest rates, when all prices experience continuous increases in a long time, inflation will occur. In addition, if the interest rate increases, it will affect the industry, especially in credit matters. Thus the increase in BI interest rates will also rise and have an impact on commercial banks so that the lending rates are likely to increase. This proves that whenever there is an increase in the inflation rate, it will be followed by an increase in the BI Rate. 
According to Kasmir (2008) said that Return On Equity is a ratio used to measure profit after tax with own capital, high Return On Equity (ROE) reflects the company's ability to generate high profits for shareholders. Then the higher the stock to buy. The existence of this will cause the demand for shares to increase and cause the stock price to continue to rise and the value of the company will also increase. Debt to Equity Ratio (DER) is a value that describes the ability of an issuer to fulfill all of its responsibilities, for example in debt repayment, if there is an increase in debt value in a company it will result in a high Debt To Equity Ratio, which means the higher interest expense companies that later affect the value of net income to be received. The results of the study conducted by Guspitasari (2013) say that simultaneously the inflation rate, interest rate and Debt To Equity Ratio (DER) have a positive effect on Company Value.

\section{Conclusion}

Based on data analysis and hypothesis testing conclusions can be obtained as follows :

a) Based on the testing of hypotheses using the variable interest rate $t$ test does not have a significant effect on the value of insurance sector companies listed on the Indonesia Stock Exchange.

b) Based on hypothesis testing using $t$ test debt variable measured by Debt Equity Ratio (DER) has no significant effect on the value of insurance sector companies listed on the Indonesia Stock Exchange.

c) Based on hypothesis testing using t test profitability variables measured by Return On Equity (ROE) have a significant effect on the value of insurance sector companies listed on the Indonesia Stock Exchange.

d) Based on testing using the F Test has no significant effect together between the independent variables: Inflation, Interest Rate, Return On Equity Ratio (ROE), and Debt To Equity Ratio (DER) to the value of the insurance sector companies listed on the Indonesia Stock Exchange 2013-2017 period.

e) Based on the coefficient of determination, the results obtained $13.8 \%$, this shows the effect of independent variables on the non-independent variable by $13.8 \%$, the remaining $86.2 \%$ is influenced by other factors, such as macroeconomic conditions, the level of competition, type and quality of products etc.

\section{Recommendation}

a) For investors, it is better to pay more attention to good financial performance that is able to explain the Company Value is greater than the financial performance that is not good and is able to increase its operational costs so that the Company's Value will improve.

b) For companies to manage the insurance sector to be more efficient in operating the company so that an increase in the independent variable can increase the greater value of the Company.

c) For the next researcher, it is expected to add the variables under study in order to obtain comprehensive and integrative results.

\section{References}

[1] H. S. Ardhi, H. A. Hasan, Y. Efni, A. Rokhmawati, and Gusnardi, J. Akuntansi, Kewirausahaan, Dan Bisnis (2017)

[2] S. Azizah and M. P. Priyadi, J. Ilmu Dan Ris. Akunt. 5, (2016) 
[3] S. dan Soebiantoro, J. Manaj. Dan Kewirausahaan 9, 41 (2007)

[4] F. Demir, White Pap. Dep. Econ. Univ. Oklahoma (2007)

[5] A. S. M. Dewi and A. Wirajaya, E-Jurnal Akunt. 4, 358 (2013)

[6] I. Fahmi, Manajemen Investasi Edisi 2 (Salemba Empat, Jakarta, 2015)

[7] I. Fahmi, Pengantar Teori Portofolio Dan Analisis Investasi (Alvabeta, Bandung, 2015)

[8] I. Ghozali, Aplikasi Analisis Multivariate Dengan Program SPSS (Badan Penerbit Universitas Diponegoro, 2006)

[9] Guspitasari, J. Ekon. Dan Pendidik. 8, 112 (2013)

[10] H. Hamidah, H. Hartini, and U. Mardiyati, JRMSI-Jurnal Ris. Manaj. Sains Indones. 6, 395 (2015)

[11] A. Hasymi, Dasar-Dasar Asuransi (Balai Aksara, Jakarta, 1981)

[12] Hery, Analisis Laporan Keuangan (Kompas Gramedia, Jakarta, 2016)

[13] A. Ira Roshita Dewi and L. Sri Artini, E-Jurnal Manaj. Univ. Udayana (2016)

[14] A. Martono and A. Harjito, Manajemen Keuangan. Edisi Pertama (Ekonesia, Yogyakarta, 2008)

[15] M. R. Noerirawan, Pengaruh Faktor Internal dan Eksternal Perusahaan Terhadap Nilai Perusahaan (Studi Empiris Pada Perusah. Manufaktur Yang Terdaftar Di Bursa Efek Indones. Periode 2007-2010) (2012)

[16] S. Nurchanifia, (2012)

[17] S. Park, Financ. Anal. J. 53, 52 (1997)

[18] D. W. Pereira Garmendia, Available SSRN 1802431 (2010)

[19] T. Pramana, Jawa Timur Sinar Ilmu Publ. (2011)

[20] T. Pramana, Jawa Timur Sinar Ilmu Publ. (2011)

[21] F. PrasetyorinI and B. Fitri, J. Ilmu Manaj. 1, (2013)

[22] R. Prihantini, (2009)

[23] L. A. Rakhimsyah and B. Gunawan, InFestasi (Jurnal Bisnis Dan Akuntansi) 7, 31 (2011)

[24] L. A. Rakhimsyah and B. Gunawan, InFestasi (Jurnal Bisnis Dan Akuntansi) 7, 31 (2011)

[25] H. Suad and E. Pudjiastuti, Dasar-Dasar Manajemen Keuangan Edisi Keenam (UPP STIM YKPN, Yogyakarta, 2012)

[26] H. Suad and E. Pudjiastuti, Penerbit UPP STIM YKPN, Yogyakarta (2012)

[27] W. T. Sucuahi, J. A. E. Alvarez, M. A. M. Gudes, and R. B. B. Parsacala, Int. J. Account. Res. 42, 1 (2016)

[28] I. M. Sudana, Manajemen Keuangan Perusahaan Teori Dan Praktik (Erlangga, Jakarta, 2011)

[29] P. D. Sugiyono, Metod. Penelit. Kuantitatif, Kualitatif Dan R\&D 291, 292 (2014)

[30] M. Suharli, J. Akunt. Dan Keuang. 7, 99 (2005)

[31] M. M. Warsono, Manajemen Keuangan Perusahaan Jilid Satu Edisi Tiga (Bayumedia Publishing, Malang, 2003)

[32] M. M. Warsono, Jilid Satu, Ed. Tiga, Cetakan Pertama, Bayumedia Publ. Malang (2003)

[33] R. M. Werner, Analisis Laporan Keuangan Proyeksi Dan Valuasi Saham (Salemba Empat, Jakarta, 2013)

Nugroho Gunawan A. Sarsiti 2015. Analisis Pengaruh Eva dan Mva terhadap Return Saham pada Perusahaan Manufaktur di Bursa Efek Indonesia. Vol 13. No 2. 
Ria Fihendri 2016. Pengaruh Profitabilitas Terhadap Nilai Perusahaan Dengan Pengungkapan Corporate Social Responsibility (Csr) Sebagai Variabel Pemoderasi Pada Pt. Semen Indonesia (Tbk). Skripsi, Universitas Trunojoyo Madura : Madura.

Setiawan, Didik. 2015. Analisis Pengaruh Faktor Internal Dan Faktor Eksternal Perusahaan Terhadap Harga Saham Pada Bank Bumn Yang Terdaftar Di BEI. Skripsi Diterbitkan. Universitas Trunojoyo Madura: Jurusan Manajemen.

online

Bisnis.com, Nop 30, 2018 